\title{
An Ultrastructural Study on the Effects of Mono(2-ethylhexyl) Phthalate on Mice Testes: Cell Death and Sloughing of Spermatogenic Cells
}

\author{
By
Tat Wei TAY ${ }^{a}$, Bibin Bintang ANDRIANA ${ }^{\mathrm{a}}$, Maki ISHII ${ }^{\mathrm{b}}$, Ehn Kyoung CHOI ${ }^{\mathrm{a}}$, Xiao Bo ZHU ${ }^{\text {a }}$, Mohammad Shah ALAM ${ }^{\text {a }}$, Naoki TSUNEKAWA ${ }^{\text {a }}$, Yoshiakira KANAI ${ }^{\mathrm{a}}$ and Masamichi KUROHMARU ${ }^{\mathrm{a} *}$

\begin{abstract}
${ }^{a}$ Department of Veterinary Anatomy, Graduate School of Agricultural and Life Sciences, The University of Tokyo, 1-1-1 Yayoi, Bunkyo-ku, Tokyo, 113-8657, Japan

${ }^{b}$ Department of Developmental Neuroscience, Tokyo Metropolitan Institute for Neuroscience, 2-6 Musashidai, Fuchu,
\end{abstract} \\ Tokyo, 183-8526, Japan.
}

- Received for Publication, November 22, $2006-$

Key Words: Apoptosis, Mono(2-ethylhexyl) phthalate, Sloughing, Spermatogenic cell, TUNEL

\begin{abstract}
Summary: Mono(2-ethylhexyl) phthalate (MEHP) is a well-characterized testicular toxicant. In this study, morphological alterations of mice testes caused by repeated administrations of MEHP were examined by light and transmission electron microscopy. Prepubertal male mice were given a range of MEHP doses $(600-900 \mathrm{mg} / \mathrm{kg} / \mathrm{day})$ for 3 consecutive days in corn oil by oral gavage. Control animals were given only corn oil. Thereafter, the testes were excised, fixed in $4 \%$ paraformaldehyde for light microscopy and/or $5 \%$ glutaraldehyde for transmission electron microscopy. Then, they were embedded, and sectioned. TUNEL analysis was done to quantify the occurrence of apoptosis in the testis. Cellular damages were also observed. Results showed that administration of $700 \mathrm{mg} / \mathrm{kg}$ of MEHP caused a significant increase in TUNEL-positive cells. At the same time, mice treated with higher doses of MEHP showed presence of degenerating (apoptotic and necrotic) spermatogenic cells. Appearance of small vacuoles in the Sertoli cell cytoplasm and displacement of spermatogenic cells were also observed. Sloughed and shed spermatogenic cells found in the tubular lumen were identified to be necrotic and apoptotic in appearance, respectively.
\end{abstract}

Di(2-ethylhexyl) phthalate (DEHP) is one of the most common plasticizer used in consumer products, food packaging materials ${ }^{1}$, and biomedical devices ${ }^{2}$. Studies on DEHP have shown that it reduces fertility and induces testicular atrophy in laboratory animals ${ }^{3)}$. When administered orally to rodents, DEHP is rapidly hydrolyzed in the gut and other tissues by nonspecific esterases to produce its monoester metabolite, mono (2-ethylhexyl) phthalate (MEHP) ${ }^{4}$. MEHP has been found to be the active toxic metabolite of $\mathrm{DEHP}^{5}$. Previous researches have shown that young (sexually immature) animals are more sensitive to MEHP exposure $^{6)}$ and that the Sertoli cells are the primary target of MEHP in the testis ${ }^{7}$. Loss of spermatogenic cells attached to the seminiferous epithelium and appearance of spermatogenic cells within the lumen are the phenomena frequently observed with several Sertoli cell toxicants, including phthalates ${ }^{8,9)}$.

The interaction between Sertoli and spermatogenic cells is crucial for spermatogenic cell maturation, and the toxic effect of MEHP on Sertoli cells may lead to spermatogenic cell death ${ }^{10)}$. It has been known that vacuolation in Sertoli cells is the earliest morphological sign of testicular injury and the cardinal response seen with many of the Sertoli cell toxicants ${ }^{8}$. Disruption to the Sertoli-spermatogenic cell physical interaction might also cause spermatogenic cell sloughing ${ }^{11,12)}$. These alterations, if permitted to carry on, will initially lead to a progressive loss of normal spermatocytes, which in turn will cause the number of viable spermatids to decrease.

* Corresponding author: M. Kurohmaru, Department of Veterinary Anatomy, Graduate School of Agricultural and Life Sciences, The University of Tokyo, 1-1-1 Yayoi, Bunkyo-ku, Tokyo, 113-8657, Japan. E-mail address: amkuroh@mail.ecc.u-tokyo.ac.jp 
Since Sertoli cells are responsible for directing spermatogenic cell differentiation and survival, the disrupted Sertoli cells as a result of MEHP treatment may induce premature spermatogenic cell death. Thus, the objective of the present study was to characterize the physical damage caused by repeated administrations of MEHP on Sertoli and spermatogenic cells in young mice testes.

\section{Materials and Methods}

Twenty-eight-day-old $\mathrm{C} 57 \mathrm{Bl} / 6 \mathrm{~N}$ male mice (Charles River, Co., Japan) were given daily doses of MEHP $(600 \mathrm{mg} / \mathrm{kg}, 700 \mathrm{mg} / \mathrm{kg}, 800 \mathrm{mg} / \mathrm{kg}$, or $900 \mathrm{mg} / \mathrm{kg}$, respectively) in corn oil by oral gavage for 3 consecutive days. Mice received MEHP in corn oil at a volume equal to $4 \mathrm{ml} / \mathrm{kg}$. Control animals received the same volume of corn oil. MEHP was purchased from Tokyo Kasei Kogyo Co., Ltd. (Tokyo, Japan). Mice were sacrificed, and then the testes were excised. For TUNEL (terminal deoxy-nucleotidyl transferase-mediated digoxigenin-dUTP nick-end labeling) analysis, the specimens were fixed in $4 \%$ PFA (paraformaldehyde) in phosphate-buffered saline (PBS) at $4^{\circ} \mathrm{C}$. Thereafter, they were dehydrated in ethanol, cleared in xylene, and embedded in paraffin. Paraffin blocks were cut at $5 \mu \mathrm{m}$ in thickness.

The TUNEL method was carried out according to the protocol of the 'in situ apoptosis detection kit' (TaKaRa, Tokyo, Japan). The paraffinembedded sections were deparaffinized, rehydrated, and then predigested with $10 \mu \mathrm{g} / \mathrm{ml}$ protease $\mathrm{K}$ for $15 \mathrm{~min}$. Thereafter, sections were incubated in PBS containing $3 \% \mathrm{H}_{2} \mathrm{O}_{2}$ for $15-$ $30 \mathrm{~min}$ to block endogenous peroxidase activity. Then, they were incubated with a fluorescein isothiocyanate (FITC)-labeled TdT enzyme in a humidified chamber at $37^{\circ} \mathrm{C}$ for $90 \mathrm{~min}$. After washing, the slides were incubated with anti-FITC HRP (horseradish peroxidase) conjugate at $37^{\circ} \mathrm{C}$ for $30 \mathrm{~min}$. Finally, TUNEL positive cells were detected by DAB (3,3'-diaminobenzidine tetrahydrochloride) substrate development, counterstained with methyl green dye, mounted, and observed using optical microscopy. To check for the nonspecific reaction, the sections were incubated with PBS buffer alone instead of FITC-labeled TdT enzyme. The incidence of apoptosis was reported as the total number of TUNEL-positive cells per 50 randomly selected round seminiferous tubules.

Data are expressed as means \pm SE. Statistical analysis was conducted using the Student's $t$ test. $P$ values of less than 0.05 were considered statistically significant.
For transmission electron microscopy, the excised testes were fixed in 5\% glutaraldehyde in PBS at $4^{\circ} \mathrm{C}$ for $2 \mathrm{hr}$. Thereafter, they were cut into small cubes $(1 \times 1 \times 1 \mathrm{~mm})$, and placed in the same solution at $4^{\circ} \mathrm{C}$ for an additional $1 \mathrm{hr}$. The samples were then washed with the same buffer for $5 \mathrm{~min}$, postfixed in $1 \%$ osmium tetroxide at $4^{\circ} \mathrm{C}$ for 90 $120 \mathrm{~min}$, and dehydrated in an ascending ethanol series. Finally, they were infiltrated with propylene oxide, and embedded in Araldite M. Semithin $(1 \mu \mathrm{m}$ thick) sections were stained with $1 \%$ toluidine blue and examined to assess pathological changes by light microscopy. Ultrathin sections (70-90 nm thick) were stained with uranyl acetate and lead citrate, and examined under a JEM $1200 \mathrm{EX}$ transmission electron microscope at $60 \mathrm{kV}$.

\section{Results}

Figure 1 shows results from the TUNEL analysis. TUNEL-positive cells were detected in control mice (Fig. 1A) and also in mice treated with $700 \mathrm{mg} / \mathrm{kg}$ MEHP (Fig. 1B). The graph in Fig. 1C shows that mice treated with $700 \mathrm{mg} / \mathrm{kg}$ and $800 \mathrm{mg} / \mathrm{kg}$ MEHP had a quite significant increase in TUNEL-positive cells $(\mathrm{p}<0.001)$ compared to the control group. Although mice treated with $800 \mathrm{mg} / \mathrm{kg}$ MEHP also had a significant increase in TUNEL-positive cells, the number recorded was relatively less, compared to mice treated with $700 \mathrm{mg} / \mathrm{kg}$ MEHP. Interestingly, a significant increase in TUNEL-positive cells was not observed in mice treated with the highest dose.

Semithin sections of control and treated mice are shown in Fig. 2. A cross section from a control mouse testis is shown in Fig. 2A. Spaces within the seminiferous epithelia were observed in mice treated with $600 \mathrm{mg} / \mathrm{kg}$ MEHP (Fig. 2B). Meanwhile, mice treated with $700 \mathrm{mg} / \mathrm{kg}$ MEHP showed presence of darkly stained spermatogenic cells, which is an indication of cell death development (Fig. 2C). As the dose increased, sloughing of spermatogenic cells into the lumen occurred, and presence of single, small vacuoles was also detected (Fig. 2D). Then, at $900 \mathrm{mg} / \mathrm{kg}$ MEHP, disruption of Sertoli cells was severer, whereby breakage was observed along with some spermatogenic cell sloughing (Fig. 2E).

Figure 3 shows transmission electron micrographs of control (Fig. 3A) and $700 \mathrm{mg} / \mathrm{kg}$ MEHP treated (Fig. 3B-F) mice testes. In the treated mice, appearance of vacuoles, as well as heterochromatin condensation, could be seen in some spermatocytes (Fig. 3B). An apoptotic spermatogonium, beside a normal Sertoli cell, could also be found (Fig. 3C). A 

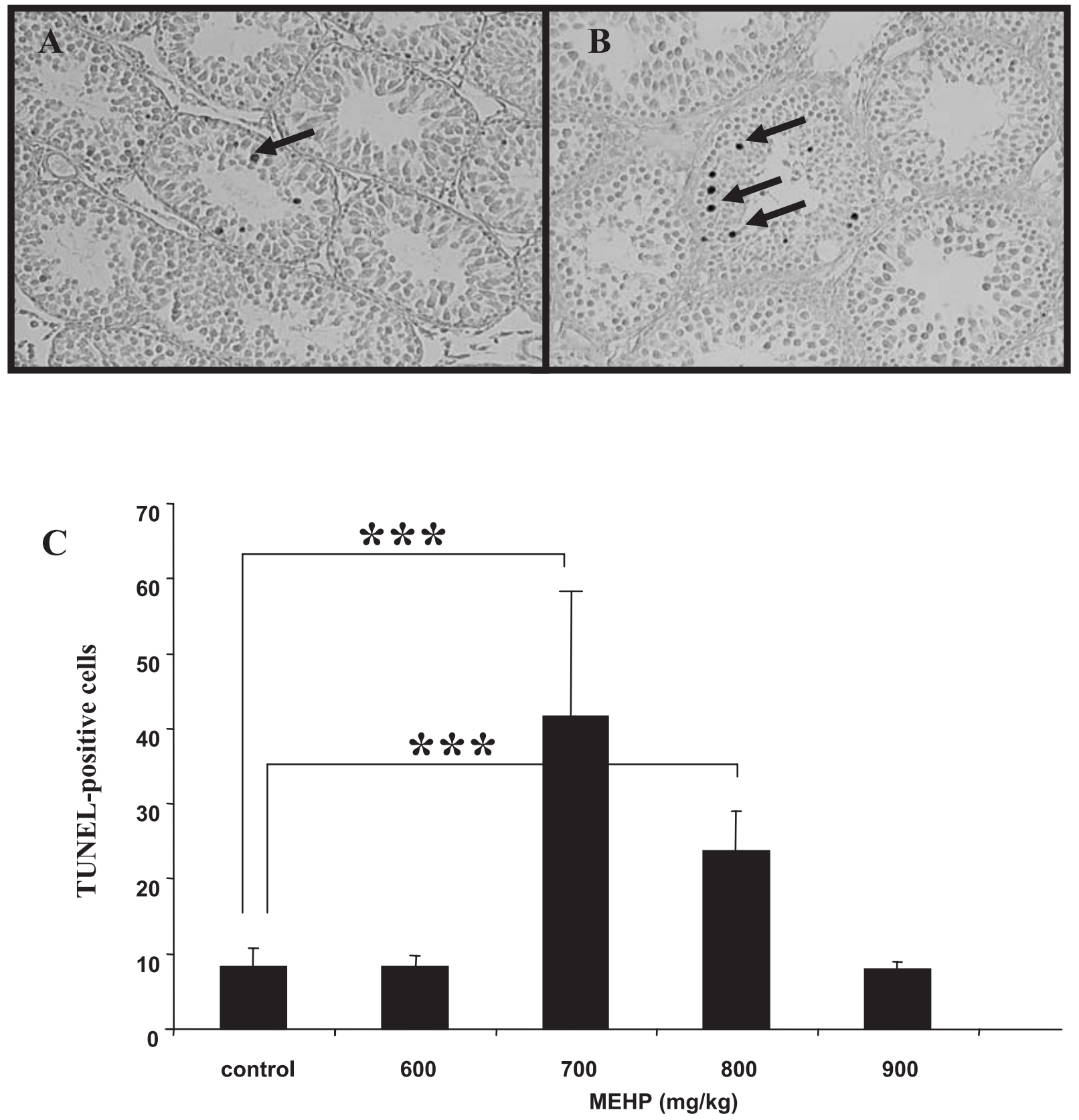

Fig. 1. A-B: Light micrographs showing TUNEL analysis in control and $700 \mathrm{mg} / \mathrm{kg}$ MEHP treated mice testes. All figures are magnified at $\times 50$. A: The presence of TUNEL-positive cells is detected in a control mouse testis. B: In a treated mouse testis, TUNEL-positive cells are more frequent (arrows). C: Number of TUNEL-positive cells per 50 seminiferous tubules. Data are represented as mean $\pm \mathrm{SEM}$. Mice treated with $700 \mathrm{mg} / \mathrm{kg}$ and $800 \mathrm{mg} / \mathrm{kg}$ MEHP show a quite significant difference $(\mathrm{p}<0.001)$ compared to control.

higher magnification of the apoptotic cell is shown in Fig. 3D. Here, we could observe the presence of a large vacuole and a slight shrinkage of the nuclear membrane. Presence of intact and functioning mitochondria was also detected. Meanwhile, 2 necrotic spermatocytes with enlarged cytoplasm were also observed (Fig. 3E). A higher magnification of the necrotic cell showed nuclear membrane lysis, which is a typical indication of necrotic event (Fig. 3F).

Other than spermatogenic cell death, MEHP was also found to cause appearance of vacuoles and displacement of spermatogenic cell towards the lumen, especially in mice treated with high 


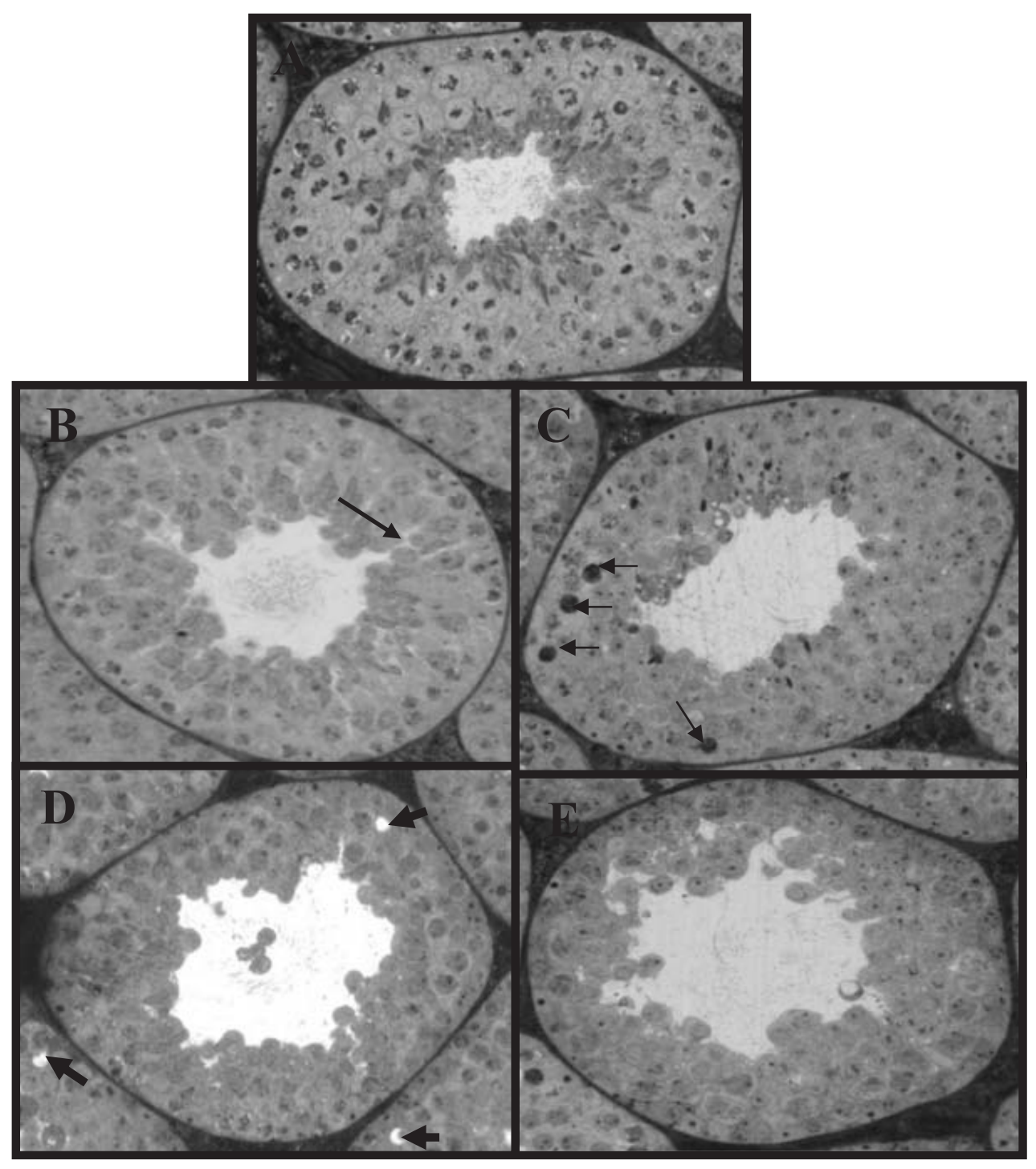

Fig. 2. A-E: Semithin sections of seminiferous tubules of control (A) and MEHP treated (B-E) mice. (Toluidine blue stained). All figures are magnified at $\times 100$. A: Control. B: Mouse treated with $600 \mathrm{mg} / \mathrm{kg}$ MEHP showing spaces between Sertoli cell cohorts (arrow). C: Darkly stained spermatogenic cells (small arrows) are observed in a mouse treated with $700 \mathrm{mg} / \mathrm{kg} \mathrm{MEHP}$. D: Presence of single, small vacuoles (arrowheads) begins to appear in a $800 \mathrm{mg} / \mathrm{kg}$ MEHP-treated mouse. A few sloughed spermatogenic cells are also observed in the tubular lumen. E: Mouse treated with $900 \mathrm{mg} / \mathrm{kg}$ MEHP showing severe disruption of Sertoli cells with breakage observed along with some spermatogenic cell sloughing.

doses of MEHP (Fig. 4A and B). This displacement indicates a certain kind of disruption in the Sertoli cells, which causes it to lose its hold of nearby spermatogenic cells. Fig. 4C shows a magnified normal spermatogenic cell located near the displacement. The presence of functioning mitochondria and also a small vacuole was detected.

More prominent effects of MEHP could be seen in the sloughing of spermatogenic cells into the tubular lumen (Fig. 5B). Although 'sloughing' is known to be the result of chemical injury, 'shedding', on the other hand, is known to happen even in a normal condition (Fig. 5A). These detached spermatogenic cells were identified to be undergoing cell death processes, either apoptosis (Fig. 5C and E) or necrosis (Fig. 5D).

\section{Discussion}

Prepubertal mice were used in this experiment, because they are more sensitive to the reproductive effects of phthalate esters ${ }^{13,14)}$. The higher sensitivity of young mice to phthalate esters should be 

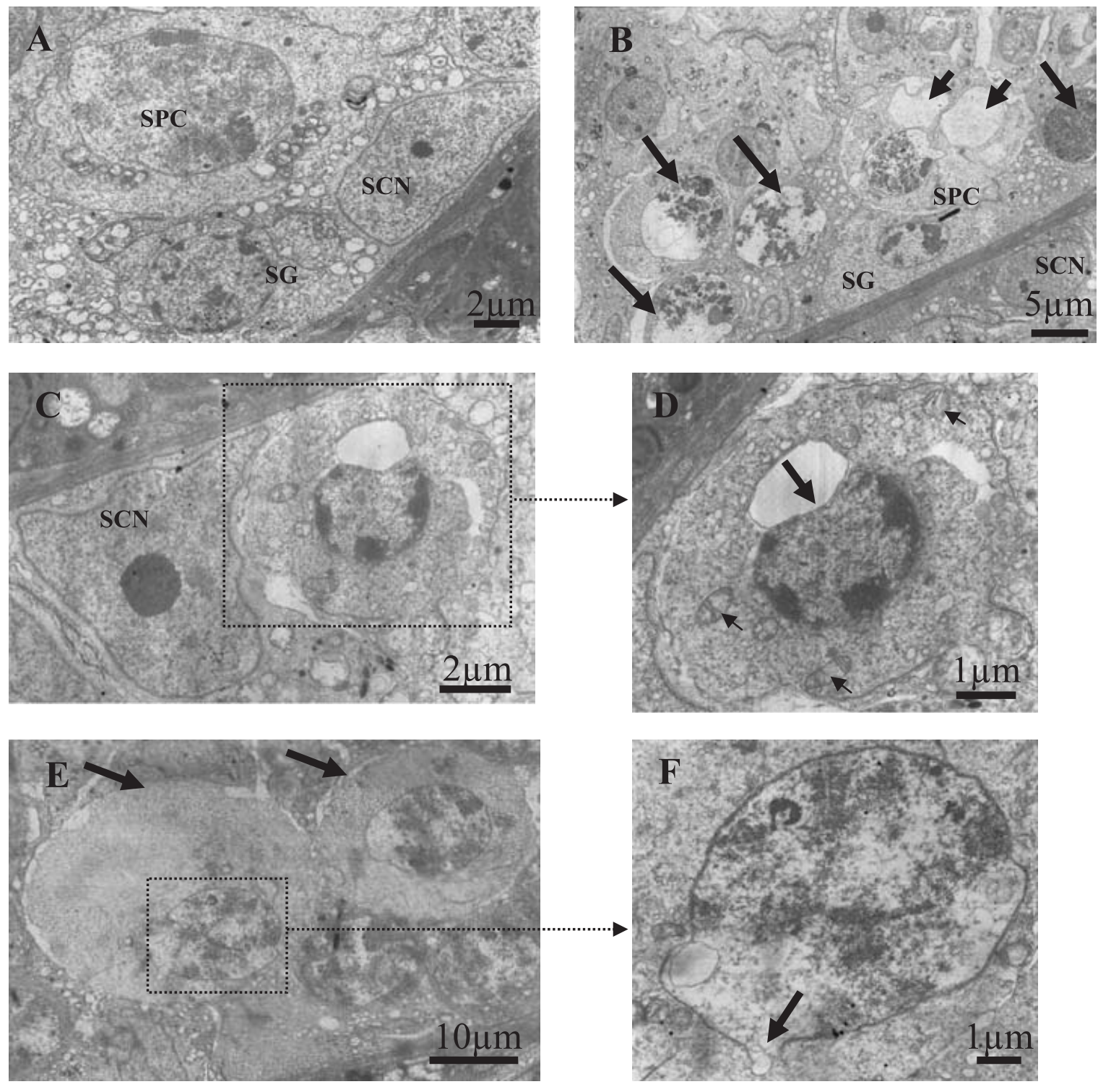

Fig. 3. A-F: Transmission electron micrographs of control (A) and $700 \mathrm{mg} / \mathrm{kg}$ MEHP treated (B-F) mice. A: Control mice showing normal Sertoli cell nucleus (SCN), spermatogonium (SG) and spermatocyte (SPC). B: Presence of 2 large vacuoles (arrowheads) and heterochromatin condensation (arrows) can be seen in a few spermatocytes. C: An apoptotic spermatogonium beside a normal Sertoli cell. D: Higher magnification of the apoptotic cell showing presence of a large vacuole and a slight shrinkage of the nuclear membrane (arrow). Presence of intact and functioning mitochondria is also detected (small arrows). E: Two necrotic spermatocytes with enlarged cytoplasm (arrows). F: Higher magnification of the necrotic cell showing heterochromatin condensation and nuclear membrane lysis (arrow).

due to the differences in absorption, distribution, and metabolism of phthalate esters between young and adult (sexually mature) individuals ${ }^{15}$. Moreover, spermatogenic cell apoptosis normally occurs in young mice to limit the clonal expansion of spermatocytes. Therefore, young mice provide a convenient model to evaluate alterations in the process of apoptosis.

MEHP has a half-life of approximately 3-5 hr, so that within $24 \mathrm{hr}$ more than $90 \%$ of the com- pound is eliminated ${ }^{16)}$. However, one finding ${ }^{3)}$ noted that a single dose of $800 \mathrm{mg} / \mathrm{kg}$ MEHP caused significant testicular atrophy at 7 days after administration in rats, while a single dose of $400 \mathrm{mg} / \mathrm{kg}$ MEHP was not very pronounced. Since testicular toxicity generally occurs after multiple rather than single exposures, the current experiment used a consecutive 3 days exposure period. In addition, data from our preliminary results showed that doses above $1000 \mathrm{mg} / \mathrm{kg}$ had fatal effects on 

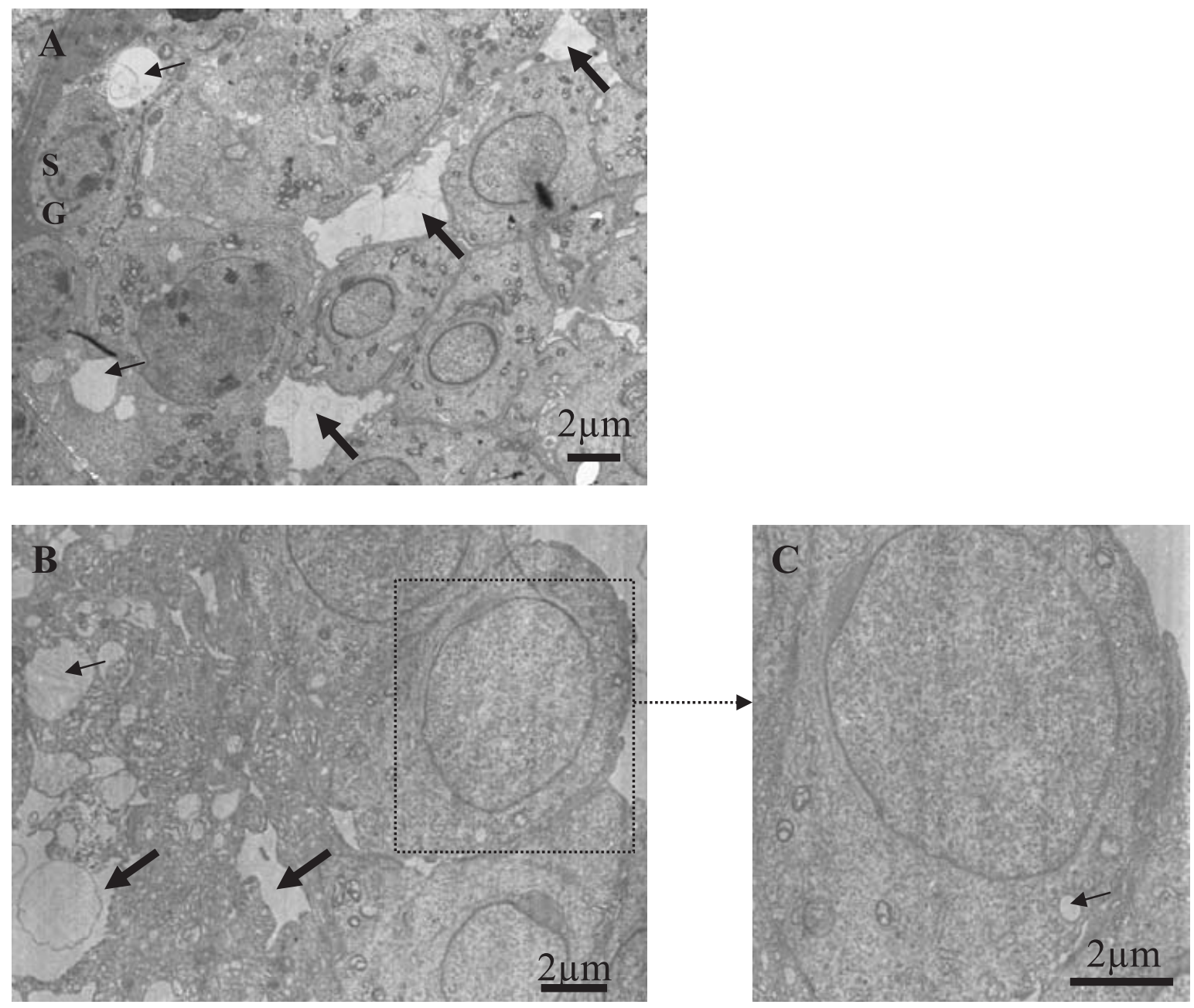

Fig. 4. A-C: Transmissions electron micrographs of mice treated with $900 \mathrm{mg} / \mathrm{kg}$ (A) and $800 \mathrm{mg} / \mathrm{kg}$ MEHP (B-C). A-B: Vacuolation of the Sertoli cell cytoplasm (small arrows) and displacement of spermatogenic cells towards the lumen due to vacuolation (arrows). C: Higher magnification of a spermatogenic cell located near the tubular lumen. Normal mitochondria can be seen along with the presence of a small vacuole (small arrow).

mice. Therefore, the dose range was determined between 600-900 mg/kg MEHP.

The increase of apoptotic spermatogenic cells is often observed in testes injured by various physical or chemical stimuli ${ }^{17}$. The primary consequence of MEHP exposure is a large increase in spermatogenic cell apoptosis ${ }^{18)}$, and a high dose of MEHP could induce early spermatogenic cell death ${ }^{19}$, which was coherent with our findings. Interestingly, in our experiment, mice treated with doses higher than $700 \mathrm{mg} / \mathrm{kg}$ MEHP did not show dosedependency. The inability to detect TUNELpositive cells in those mice could be due to the fact that either dead cells were already removed by sloughing or engulfed by Sertoli cells. It is believed that the effects of MEHP on Sertoli cells may lead spermatogenic cells to sloughing into tubular lumen $^{8,20)}$, and our findings showed occasional pre- sence of spermatogenic cells within the testicular lumen. Unfortunately, the role of phagocytosis in MEHP exposure can not be ascertained at present and requires further exploration.

In the present study, the appearance of apoptotic and necrotic spermatogenic cells was frequently observed. In general, apoptotic cells were classified based on the presence of vacuoles, heterochromatin condensation, and cell disintegration without an inflammatory response ${ }^{21)}$. While, necrosis was characterized by swollen cytoplasm and/or mitochondria, appearance of vacuoles, condensed chromatin in the nucleus, and nuclear membrane lysis ${ }^{22)}$.

Other than spermatogenic cell death, disruption in the Sertoli cell physical structure (vacuolation and spermatogenic cell displacement) was also observed after MEHP exposure. It is known that 


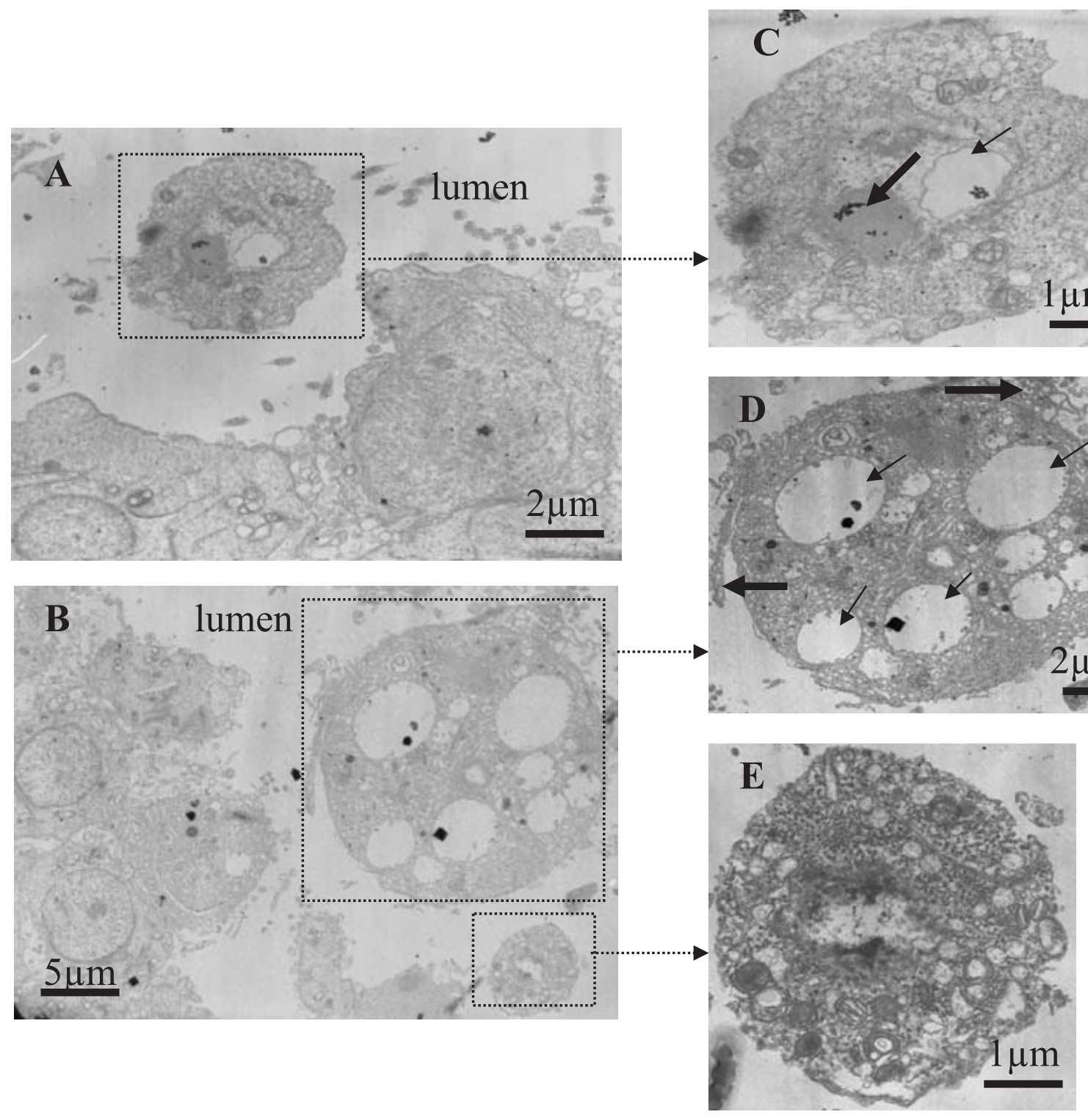

Fig. 5. A-E: Transmission electron micrographs of control (A \& C) and $800 \mathrm{mg} / \mathrm{kg}$ MEHP treated (B, D and E) mice showing presence of spermatogenic cells in the tubular lumen. A-B: Detached spermatogenic cells. C: (Shedding) An apoptotic spermatogenic cell found in one of the control mice showing presence of a vacuole (small arrow) and heterochromatin condensation (arrow). D: (Sloughing) A large necrotic spermatogenic cell showing swollen mitochondria (small arrows) and fragments of Sertoli cell cytoplasm still adhered to it (arrows). E: An apoptotic spermatogenic cell with intact mitochondria and heterochromatin condensation.

vacuolation is the earliest morphological sign of testicular injury and the cardinal response seen with many of the Sertoli cell toxicants. In our findings, the presence of a few small vacuoles in the Sertoli cell cytoplasm accompanied by displacement of spermatogenic cells towards the lumen was observed, which is a prominent feature of the early response to phthalate exposure in young rodents ${ }^{23)}$. A higher magnification of the displaced spermatogenic cells shows normal attributes, except for the presence of one small vacuole in the cytoplasm. We believe that the appearance of the vacuole is actually the first step towards cell death. Without the support and nurture provided by Sertoli cells, detached spermatogenic cells can no longer survive and will eventually die.

The presence of sloughed cells within the tubular lumen has been reported. Many Sertoli cell toxicants, including phthalates, result in appearance of spermatogenic cells within the lumen ${ }^{8)}$, but there is hardly any information about the types of sloughed cells. First of all, we have to clarify that there are 2 
types of sloughing. First, 'apical sloughing', which is defined as toxicant-induced detachment of spermatogenic cells adherent to fragments of membranebounded apical Sertoli cell cytoplasm ${ }^{24)}$. Second, 'shedding', defined as the release of spermatogenic cells from the seminiferous epithelium without adhered fragments of Sertoli cell cytoplasm ${ }^{7)}$. In most instances, detailed ultrastructural studies have not been performed to distinguish apical sloughing from shedding. Fortunately, results from our study showed a sloughed spermatogenic cell with fragments of Sertoli cell cytoplasm still adhered to it. This cell was found to be necrotic with multiple swollen mitochondria. Meanwhile, shedding was observed in the control and treated mice. The shed spermatogenic cells were of the apoptotic type. Although shedding of spermatogenic cells is not uncommon, we were unable to determine at this point in time if MEHP exposure also caused shedding in the treated mice.

In conclusion, our study found that repeated MEHP exposure in mice caused a significant increase in TUNEL-positive spermatogenic cells, vacuolation in the Sertoli cells, and displacement of spermatogenic cells towards the lumen. We also managed to identify detached spermatogenic cells in the tubular lumen to be either 'sloughing' or 'shedding' events, with sloughed cells being necrotic and shed cells being apoptotic in appearance.

\section{Acknowledgements}

This work was supported in part by Grant-in-Aid for Scientific Researchers from the Ministry of Health, Labor and Welfare, and from the Ministry of Education, Culture, Sports, Science and Technology, Japan.

\section{References}

1) Blount BC, Milgram KE, Silva MJ, Malek NA, Reidy JA, Needham LL and Brock JW. Quantitative detection of eight phthalate metabolites in human urine using HPLCAPCI-MS/MS. Anal Chem 2000; 72:4127-4134.

2) Cole RS, Tocchi M, Wye E, Villeneuve DC and Rock G. Contamination of commercial blood products by di-2ethylhexyl phthalate and mono-2-ethylhexyl phthalate. Vox Sang 1981; 40:317-322.

3) Teirlynck OA, Kaufman JM, Bogaert MG and Roels H. Testicular toxicity induced by single dosing of di- and mono-(2-ethylhexyl) phthalate in the rat. Toxicol Lett 1988; 40:85-91.

4) Albro PW and Thomas RO. Enzymatic hydrolysis of di(2ethylhexyl) phthalate by lipases. Biochim Biophys Acta 1973; 306:380-390.

5) Oishi $\mathrm{S}$ and Hiraga K. Testicular atrophy induced by phthalic acid esters: effect on testosterone and zinc concentrations. Toxicol Appl Pharmacol 1981; 53:35-41.

6) Poon R, Lecavalier P, Mueller R, Valli VE, Procter BG and Chu I. Subchronic oral toxicity of di-n-octyl phthalate and di(2-ethylhexyl) phthalate in the rat. Food Chem Toxicol 1997; 35:225-239.

7) Boekelheide K. Sertoli cell toxicants. In: Russell LD and Griswold M, eds, The Sertoli Cell Florida, Cache River Press, 1993; 551-575.

8) Creasy DM, Beech LM, Gray TJ and Butler WH. The ultrastructural effects of di-n-pentyl phthalate on the testis of the mature rat. Exp Mol Pathol 1987; 46:357-371.

9) Gray TJB and Beamand JA. Effects of some phthalate esters and other testicular toxins on primary cultures of testicular cells. Fd Chem Toxicol 1984; 22:123-131.

10) Bartke A. Apoptosis of male germ cells, a generalized or a cell type-specific phenomenon? Endocrinology 1995; 136:3-4.

11) Thomas JA and Thomas MJ. Biological effects of di-(2ethylhexyl) phthalate and other phthalic acid esters. Crit Rev Toxicol 1984; 13:283-317.

12) Albro PW. The biochemical toxicology of di-(2-ethylhexyl) and related phthalates: Testicular atrophy and hepatocarcinogenesis. Rev Biochem Toxicol 1987; 8:73-119.

13) Gray TJB and Gangolli SD. Aspects of the testicular toxicity of phthalate esters. Environ Health Perspect 1986; 65:229-235.

14) Sjöberg P, Bondesson U, Gray TJB and Plöen L. Effects of di(2-ethylhexyl) phthalate and five of its metabolites on rat testes in vivo and in vitro. Acta Pharmacol Toxicol 1986; 58:225-233.

15) Sjöberg P, Bondesson U, Kjellen L, Lindquist NG, Montin $\mathrm{G}$ and Plöen L. Kinetics of di-(2-ethylhexyl) phthalate in immature and mature rats and effect on testis. Acta Pharmacol Toxicol 1985; 56:30-37.

16) Teirlynck OA and Belpaire F. Disposition of orally administered di-(2-ethylhexyl) phthalate and mono-(2ethylhexyl) phthalate in the rat. Arch Toxicol 1985; 57:226-230.

17) Richburg JH. The relevance of spontaneous- and chemically-induced alterations in testicular germ cell apoptosis to toxicology. Toxicol Lett 2000; 112-113:79-86.

18) Richburg JH and Boekelheide K. Mono-(2-ethylhexyl) phthalate rapidly alters both Sertoli cell vimentin filaments and germ cell apoptosis in young rat testes. Toxicol Appl Pharmacol 1996; 137:42-50.

19) Suominen JS, Linderborg J, Nikula H, Hakovirta H, Parvinen $M$ and Toppari J. The effects of mono-2-ethylhexyl phthalate, adriamycin and N-ethyl-N-nitrosourea on stagespecific apoptosis and DNA synthesis in the mouse spermatogenesis. Toxicol Lett 2003; 143:163-173.

20) Richburg JH, Nanez A, Williams LR, Embree M and Boekelheide K. Sensitivity of testicular germ cells to toxicantinduced apoptosis in gld mice that express a nonfunctional form of fas ligand. Endocrinology 2000; 141:787-793.

21) Wyllie AH. Apoptosis: cell death in tissue regulation. J Pathol 1987; 153:313-316.

22) Wyllie AH, Kerr JF and Currie AR. Cell death: the significance of apoptosis. Int Rev Cytol 1980; 68:251-306.

23) Creasy DM, Foster JR and Foster PMD. The morphological development of di-pentyl phthalate induced testicular atrophy in the rat. J Pathol 1983; 139:309-321.

24) Russell LD, Malone JP and MacCurdy DS. Effect of the microtubule disrupting agents, colchicines and vinblastine, on seminiferous tubule structure in the rat. Tissue Cell 1981; 13:349-367. 